\title{
剛性マトリックス法による中詰土を有する 壁体構造物の力学的挙動解析法の開発

\author{
A NUMERICAL CALCULATION METHOD BY STIFFNESS MATRIX \\ METHOD FOR STATIC MECHANICAL BEHAVIOR OF DOUBLE WALL \\ TYPE STRUCTURE WITH FILLING MATERIAL
}

\author{
佐藤光一 1 - 原田典佳 2 \\ Kohichi SATOH and Noriyoshi HARATA \\ 1正会員 工修 新日本製鐵株式会社 北海道支店（テ060-0002 札幌市中央区北2西4） \\ 2正会員 新日本製鐵株式会社 大阪支店（テ5530-0005 大阪市北区中之島3-2-4）
}

\begin{abstract}
A calculation method for static mechanical behavior of double wall type structure has not been established. In this paper, A numerical calculation method by stiffness matrix method is proposed to predict static mechanical behavior of double wall type structure. This proposed method applies theoretical equations that were obtained by Ohbori et al considering both the interaction between walls and filling material above ground and lateral resistance of walls under ground. Then, this method was considering elasto-plastic. behavior of filling sand and ground.

The calculated results by this proposed method coincide well with the behavior of model structures in The paper of Ohbori et al. Furthermore, to apply this proposed method for design calculation and to evaluate the behavior of new type double wall structures, several double wall type structure models were calculated.
\end{abstract}

KeyWords : Double wall type structure, stiffness matrix method, elasto-plastic behavior

\section{1.はじめに}

中詰土を有する壁体構造物の代表例として二重壁式構 造物がある. 二重壁式構造物は銅矢板や鋼管矢板等の壁 体構成部材を基礎地盤に二列に打設しここれらの頭部を夕 イ材等で連結した後,壁体間に土砂を中詰めして構造体と するものである. 構造物として完成した後に作用する土 水圧, 地震力, 波力等の水平外力に対しては, 中詰土のせん 断抵抗と壁体の剛性や根入れ部の地盤反力で抵抗する.

二重壁式構造物は, 水平外力, 特に地震時慣性力の作用 により,構造物天端には中詰土のせん断変形に伴う比較的 大きな水平変位が発生する.『港湾の施設の技術上の基 準·同解説 ${ }^{1}$ ，(以下，『技術上の基準』と略記する)』には, 次に示す主旨の記載がある。『建設実績が豊富な条件に対 して設計する場合には，慣用法 (鋼矢板セル式係船岸及び 控え工を有する矢板式係船岸の設計法を準用する方法） によることができる. しかし，慣用法では変位や断面力の 分布等力学的挙動に関する総合的な検討を行うことがで きないので, 大規模で重要な永久構造物として設計する場 合には沢口の方法または大堀ら方法によってその力学的 挙動を検討することが望ましい.』

沢口の方法”) は, 二重壁式構造物の設計地盤面上部（上 部構造）を壁体構成部材と非圧縮性弾性体と仮定した中 詰土からなる複合構造物とみなし，上部構造における二列 の壁体及び中詰土の微少水平スライス要素に関する力の
釣り合いと変形の適合条件等から導いた壁体構成部材に 関する 2 元連立 4 階微分方程式を所定の境界条件の下に 解くものである.

また, 大堀らの方法 ${ }^{3}$ は沢口の方法を発展させたもので 中詰土の圧縮特性及び中詰土と基礎地盤の弾塑性的性質 を取り入れている. しかし，文献3)では図-1(a)に示寸頂 版結合タイプの場合, 頂版を計算モデルに取り込んでいな いため, 頂版の断面設計に必要な断面力や壁体構成部材に 発生する軸方向力に関する情報等が得られないという問 題がある. また，構造体を補強するために図-1(c)に示す ように増し杭等を配置したり，図-1(d)に示すように中詰 土の天端高さを变化させる場合等一の対応も困難である.

このような状況を踏まえ, 本文では二重壁式構造物をは じめ，様々な構造·荷重·境界条件下における中詰土を有 する壁体構造物の力学的挙動を総合的に検討するために 開発した剛性マトリッス法による解析手法について報告し ている.この解析手法によれば, 後出の解析例に示すよう に頂版を計算モデルに取り込むことができ，また，増し杭 等の付加部材を配置した場合や中詰土の天端高さを低く した場合等についてもその力学的挙動を計算することが できる.

図-1 (a)〜 (d) は中詰土を有する壁体構造物の構造例を 示したものである. (a), (b) は二重壁式構造物の標淮的な 構造例で, (a) は頂版結合タイプ, (b) はタイ材結合タイ プである. (c), (d) は今回報告する解析手法によりその 
力学的挙動を計算することが可能となった構造を例示し たものである. (c)は中詰土の内部に鋼管杭を打設した増 し杭タイプ, (d)は中詰土の天端を低くし，その上部空間を 遊水室とした低天端中詰土タイプである.

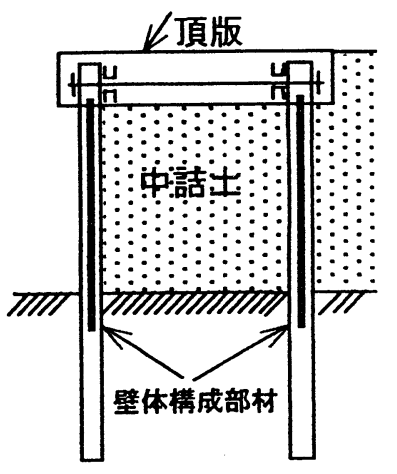

(a) 頂版結合タイプ

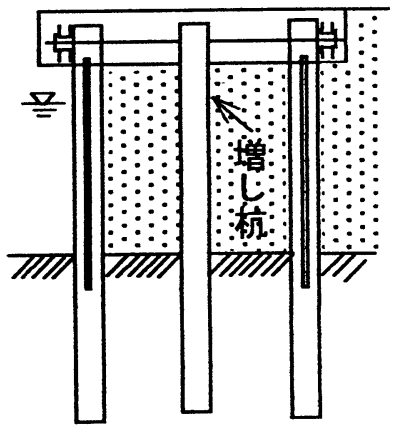

(c) 増し杭タイプ

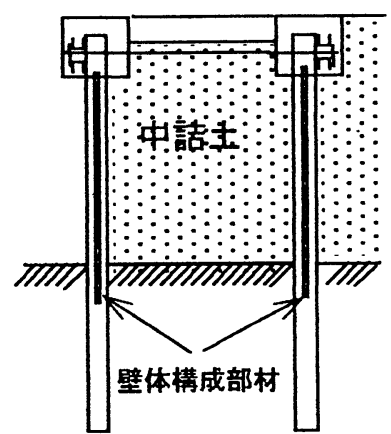

(b) タイ材結合タイプ

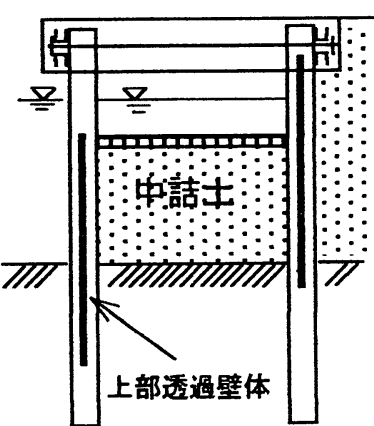

(d) 低天端中詰土タイプ
図-1 中詰土を有する壁体構造物

\section{2. 中詰土を有する壁体構造物の力学モデルと 支配方程式}

構造物完成後に作用する水平外力に対する二重壁式構造 物の設計法は, 次の 2 とおりに大別することができる. (1)中詰土のせん断抵抗のみにより抵抗するとするもの (2)中詰十のせん断抵抗と壁体の剛性及び地盤反力により

抵抗するとするもの

(1)の方法は慣用法といわれているもので, 壁体構成部材 等の变形や惭面力を計算·照査するプロセスは存在しない： (2)の方法には沢口の方法やこれを発展させた大堀らの方 法がある. 本文では, 二重壁式構造物に代表される中詰土 を有する壁体構造物の変形や断面力分布といった力学的 挙動の検討を目的としているため, 大堀らの方法で提案さ れている力学モデル及ひ壁体構成部材に関する支配方程 式を採用している.

(1) 壁体構成部材のカ学モデルと支配方程式

a) 構造物完成前（中詰土充填完了時）

大堀らの方法では仮想地盤面の上部と下部における壁体 構成部材の部材軸直角方向の挙動を次式で表わしている. (1)仮想地盤面上部における部材

$$
\text { EI } \frac{d^{4} y}{d x^{4}}=p_{1}
$$

(2)仮想地盤面下部における部材

$$
\text { EI } \frac{d^{4} y}{d x^{4}}+E_{s} y=p_{2}
$$

ここに, $x$ は部材軸方向距離, $y$ は部材軸直角方向変 位, $E I$ は部材の曲け阔性, $E_{s}\left(E_{s}=k_{h} L\right)$ は変形倸数, $k_{h}$ は横 方向地盤反力係数, $L$ は法線方向の壁体幅, $p_{1}, p_{2}$ は部材軸 直角方向分布荷重強度である.

b) 搆造物完成後（水平外力作用時）

(1)設計地盤面上部（上部構造）における部材

大堀らの方法では図-2の力学モデルを設定し図-3に示 寸設計地盤面上部の微小厚さの水平スライス要素に対し て, 力の釣り合い及ひ変形の適合条件, 中詰土に発生する せん断力と平均せん断ひずみの関係及び中詰士に発生す る圧縮応力と平均圧縮ひずみの関係を適用することによ り,設計地盤面上部における壁体構成部材の部材軸直角方 向の挙動を次式で表わしている.

$$
\begin{gathered}
E I \frac{d^{4}}{d x^{4}}\left(y_{A}+y_{B}\right)-\frac{B G}{2} \frac{d^{2}}{d x^{2}}\left(y_{A}+y_{B}\right)-k \gamma B=p_{A}+p_{B} \\
E I \frac{d^{4}}{d x^{4}}\left(y_{A}-y_{B}\right)+\frac{2 E_{f}}{B}\left(y_{A}-y_{B}\right)=p_{A}-p_{B}
\end{gathered}
$$

ここに, $x$ は部材軸方向距離, $y_{A} y_{B}$ は壁体構成部材 $\mathrm{A}, \mathrm{B}$ の部材軸直角方向変位, E懏体構成部材 $\mathrm{A}, \mathrm{B}$ の曲け剛 性, $p_{A}, p_{B}$ 泣部材軸直角方向分布荷重強度, $B$ は壁体幅, $G$ は中詰土のせん断弾性係数, $k \gamma B$ は中詰土に作用寸る地 震時慣性力, $k$ は設計震度, $\gamma$ は中詰土の単位体積重量, $E_{f}$ は中詰土の圧縮弾性係数である。

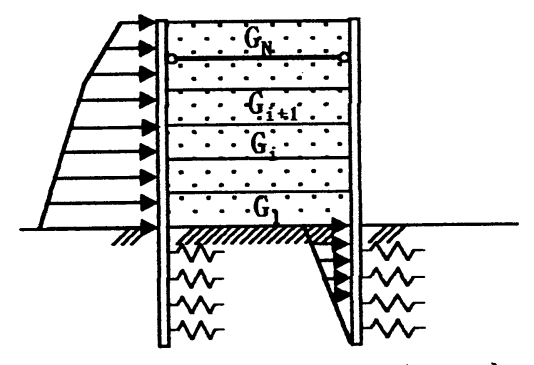

図-2 水平外力作用時の力学モデル

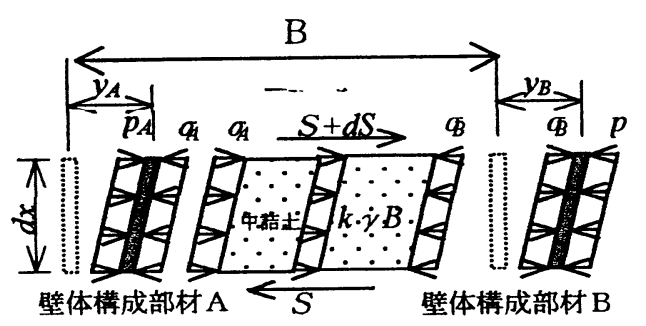

図-3 微小水平スライス要素

なお, 大堀らの方法では二重壁式構造物の非線形挙動を 反映させるために, 中詰土のせん断弾性係数 $G$ 及び圧縮 弾性係数 $E_{f}$ を次式で表わしている.

$$
G=a \sigma_{N}^{b} \theta^{c} \quad(4), E_{f}=2(1+v) G
$$

ここに, $a$ は補正係数, $b, c$ は定数, $\sigma_{N}$ は中詰土の鉛直応 力, $\theta$ はせん断ひずみ角 $\left(\theta=\left(\theta_{A}+\theta_{B}\right) / 2\right), \nu$ はポアソ ン比である.

(2)設計地盤面下部（下部構造）における部材

大堀らの方法では式(6)に示す中詰土のせん断変形に 伴うせん断力が設計地盤面上に発生するとしている.

$$
S_{\mathrm{g}}=B G_{\mathrm{g}} \theta_{\mathrm{g}}
$$


ここに, $S_{g}$ は設計地盤面における中詰士のせん断力, $G_{g}$ は設計地盤面における中詰士のせん断弾性俰数， $\theta_{g}$ は設 計地盤面における中詰士のせん断ひずみ,Bは壁体幅であ る.

そして,このせん断力は地盤伝详力として非載荷側の壁 体構成部材の地中部に逆三角形状に分布荷重として作用 するものとして,載荷側及び非載荷側における壁体構成部 材の部材軸直角方向の挙動を次式で表わしている.

・載荷側（壁体構成部材 A）

$$
E I \frac{d^{4} y_{A}}{d x^{4}}+E_{s A} y_{A}=p(x)
$$

・非載荷側（壁体構成部材 $\mathrm{B}$ )

$\mathrm{D} \geqq \mathrm{B}$ における $-\mathrm{B} \leqq \mathrm{x} \leqq 0$ の領域， $\mathrm{D}<\mathrm{B}$ におけ るーD $\leqq \mathrm{x} \leqq 0$ の領域に対して:

$$
E I \frac{d^{4} y_{B}}{d x^{4}}+E_{s B} y_{B}-\frac{2 S_{g}}{B^{2}} x+\frac{2 S_{g}}{B}=0
$$

$\mathrm{D} \geqq \mathrm{B}$ における $-\mathrm{D} \leqq \mathrm{x} \leqq-\mathrm{B}$ の領域に対して：

$$
E I \frac{d^{4} y_{B}}{d x^{4}}+E_{s B} y_{B}=0
$$

ここに, $E_{\mathrm{sA}}, E_{\mathrm{sB}}$ は壁体構成部材 $\mathrm{A}, \mathrm{B}$ の変形係数 $\left(E_{\mathrm{sA}}=k_{h A}\right.$ $\left.L, E_{s B}=k_{h B} L\right) ， k_{h A}, k_{h B}$ は壁体構成部材 $\mathrm{A}, \mathrm{B}$ 横方向地盤反力 係数, $L$ は法線方向の壁体幅, $D$ は壁体構成部材 $\mathrm{A}, \mathrm{B}$ の根 入れ長である.

\section{(2) その他の部材の力学モデルと支配方程式}

本文では，多様な構造·荷重·境界条件に対応するために, 大堀らの方法では考慮されていない頂版等の部材に関し て次に示支配方程式を適用する.

a) 設計 (仮想) 地盤面上部(上部構造)における部材

・設計(仮想) 地盤面上部の増し杭, 頂版など

・タイ材など

$$
\text { EI } \frac{d^{4} y}{d x^{4}}=p
$$

$$
E A \frac{d^{2} u}{d x}=q
$$

ここに, uは部材軸方向変位, EAは部材軸方向剛性, $q$ は部材軸方向分布荷重強度である.

b) 設計 (仮想) 地盤面下部 (下部構造)における部材

・設計(仮想)地盤面下部の增し杭など

$$
E I \frac{d^{4} y}{d x^{4}}+E_{s} y=p
$$

\section{3. 中詰土を有する壁体構造物の部材剛性方程式}

多様な構造·荷重·境界条件に対して効率的に対応でき る構造解析手法として, 剛性マトリックス法年が知られて いる. この解析手法を中詰土を有する壁体構造物に適用 するためには，構造物を構成する各部材の部材剛性方程式 を導いておく必要がある. 以下に, 前記した各部材の支配 方程式の解析解を用いて導いた部材岡性方程式を示す。

\section{(1) 壁体構成部材の部材棡性方程式}

a) 設計地盤面上部（上部構造）における部材

(1)中詰土と一体的に挙動する壁体構成部材

式(3a)，(3b)から, 部材剛性方程式として式(12)を得る.

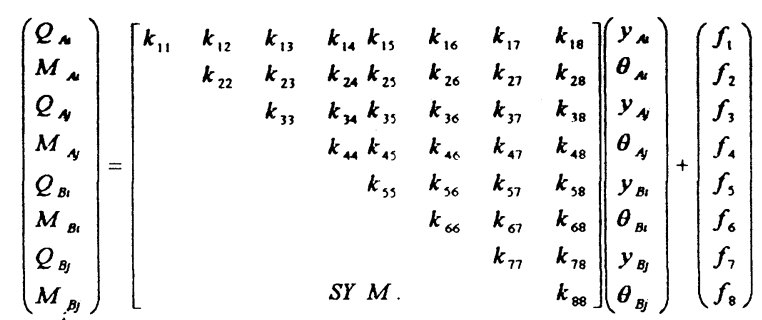

ここに, $Q_{A} ; Q_{A}$ 及び $Q_{B}, Q_{B j}$ は壁体構成部材A及ひBの $i$ 端， $j$ 端のせん断力, $M_{A i}, M_{A j}$ 及ひ $M_{B i}, M_{B J}$ は壁体構成部材A及ひB $i$ 端, $j$ 端の曲げモ一メント, $y_{A i}, y_{A j}$ 及び $y_{B i}, y_{B j}$ は壁体構

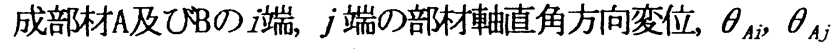
及び $\theta_{B i}, \theta_{B j}$ は壁体構成部材A及ひBのi端，j端のたわみ 角である.

式(12)の剛性マトリックスの各要素を式(13a)～(13t) に，荷重項の各要素を式(14a)～(14h)に示す.

$$
\begin{aligned}
& k_{11}=k_{55}=\frac{E I \lambda^{3} \eta}{\varepsilon}-\frac{E I \alpha^{3}\left(\chi_{2}+\omega_{2}\right)}{\delta} \\
& k_{12}=k_{56}=-\frac{E I \lambda^{2}(1-\varsigma)}{\varepsilon}-\frac{E I \alpha^{2}\left(-\phi_{2}+\psi_{2}\right)}{2 \delta} \\
& k_{13}=k_{57}=-\frac{E I \lambda^{3} \eta}{\varepsilon}+\frac{-2 E F \alpha^{3}(\phi \omega+\chi \psi)}{\vdots \delta} \\
& k_{14}=k_{58}=-\frac{E I \lambda^{2}(1-\varsigma)}{\varepsilon}-\frac{2 E I \alpha^{2} \chi \omega}{\delta} \\
& k_{22}=k_{66}=-\frac{E I \lambda^{2}(-L \varsigma+\eta / \lambda)}{\varepsilon}-\frac{E I \alpha\left(-\chi_{2}+\omega_{2}\right)}{2 \delta} \\
& k_{23}=k_{67}=-\frac{E I \lambda^{2}(\varsigma-1)}{\varepsilon}+\frac{2 E I \alpha^{2} \chi \omega}{\delta} \\
& k_{24}=k_{68}=-\frac{E L \lambda^{2}(-\eta / \lambda+L)}{\varepsilon}+\frac{E I \alpha(-\phi \omega+\chi \psi)}{\delta} \\
& k_{33}=k_{77}=\frac{E I \lambda^{3} \eta}{\varepsilon}-\frac{E I \alpha^{3}\left(\chi_{2}+\omega_{2}\right)}{\delta} \\
& k_{34}=k_{78}=\frac{E I \lambda^{2}(1-\varsigma)}{\varepsilon}+\frac{E I \alpha^{2}\left(-\phi_{2}+\psi_{2}\right)}{2 \delta} \\
& k_{44}=k_{88}=-\frac{E L \lambda^{2}(-L \varsigma+\eta / \lambda)}{\varepsilon}-\frac{E I \alpha\left(-\chi_{2}+\omega_{2}\right)}{2 \delta} \\
& k_{15}=\frac{E I \lambda^{3} \eta}{\varepsilon}+\frac{E I \alpha^{3}\left(\chi_{2}+\omega_{2}\right)}{\delta} \\
& k_{16}=k_{25}=-\frac{E I \lambda^{2}(1-\varsigma)}{\varepsilon}+\frac{E I \alpha^{2}\left(-\phi_{2}+\psi_{2}\right)}{2 \delta} \\
& k_{17}=k_{35}=-\frac{E I \lambda^{3} \eta}{\varepsilon}-\frac{2 E I \alpha^{3}(\phi \omega+\chi \psi)}{\delta} \\
& k_{18}=k_{45}=-\frac{E I \lambda^{2}(1-\varsigma)}{\varepsilon}+\frac{2 E I \alpha^{2} \chi \omega}{\delta} \\
& k_{26}=-\frac{E I \lambda^{2}(-L \varsigma+\eta / \lambda)}{\varepsilon}+\frac{E I \alpha\left(-\chi_{2}+\omega_{2}\right)}{2 \delta} \\
& k_{27}=k_{36}=-\frac{E I \lambda^{2}(\varsigma-1)}{\varepsilon}-\frac{2 E I \alpha^{2} \chi \omega}{\delta} \\
& k_{28}=k_{46}=-\frac{E I \lambda^{2}(-\eta / \lambda+L)}{\varepsilon}-\frac{E I \alpha(-\phi \omega+\chi \psi)}{\delta} \\
& k_{37}=\frac{E I \lambda^{3} \eta}{\varepsilon}+\frac{E I \alpha^{3}\left(\chi_{2}+\omega_{2}\right)}{\delta} \\
& k_{38}=k_{47}=\frac{E I \lambda^{2}(1-\varsigma)}{\varepsilon}+\frac{E I \alpha^{2}\left(-\phi_{2}+\psi_{2}\right)}{2 \delta} \\
& k_{48}=-\frac{E I \lambda^{2}(-L \varsigma+\eta / \lambda)}{\varepsilon}+\frac{E I \alpha\left(-\chi_{2}+\omega_{2}\right)}{2 \delta}
\end{aligned}
$$




$$
\begin{aligned}
& f_{1}=\left(-\frac{\lambda L^{2} \eta}{12 \varepsilon}+\frac{1}{2 \lambda^{2} L}-\frac{L}{8}\right)\left(p_{A_{A}}+p_{B_{1}}\right) \\
& +\left(\frac{\lambda L^{2} \eta}{12 \varepsilon}-\frac{1}{2 \lambda^{2} L}-\frac{L}{8}\right)\left(p_{\mu}+p_{B j}\right) \\
& +\frac{1}{8 \alpha^{2} \delta L}\left\{\left(\phi_{2}-\psi_{2}-4 \chi \omega+2 \alpha L \chi_{2}+2 \alpha L \omega_{2}\right)\left(p_{\mu}-p_{B_{t}}\right)\right. \\
& \left.+\left(-\phi_{2}+\psi_{2}-4 \alpha L \phi \omega-4 \alpha L \chi \psi+4 \chi \omega\right)\left(p_{\mu}-p_{B}\right)\right\} \\
& f_{2}=\frac{1}{\varepsilon}\left(-\frac{L^{2} \zeta}{3}+\frac{L \eta}{2 \lambda}+\frac{\varepsilon}{2 \lambda^{2}}-\frac{L^{2}}{6}\right)\left(p_{A_{i}}+p_{B i}\right) \\
& +\frac{1}{\varepsilon}\left(-\frac{L^{2} \zeta}{6}+\frac{L \eta}{2 \lambda}-\frac{L^{2}}{3}\right)\left(p_{i j}+p_{B j}\right) \\
& +\frac{1}{8 \alpha^{3} \delta L}\left\{\left(-\omega_{2}+\chi_{2}-2 \chi \psi+2 \phi \omega-\alpha L \phi_{2}+\alpha L \psi_{2}\right)\left(p_{A i}-p_{B t}\right)\right. \\
& +\left(\omega_{2}-\chi_{2}-4 \alpha L \chi \omega+2 \chi \psi-2 \phi \omega\right)\left(p_{1 j}-p_{B j}\right) \\
& f_{3}=\left(\frac{\lambda L^{2} \eta}{12 \varepsilon}-\frac{1}{2 \lambda^{2} L}-\frac{L}{8}\right)\left(p_{A i}+p_{B i}\right) \\
& +\left(-\frac{\lambda L^{2} \eta}{12 \varepsilon}+\frac{1}{2 \lambda^{2} L}-\frac{L}{8}\right)\left(p_{j j}+p_{B_{j}}\right) \\
& +\frac{1}{8 \alpha^{2} \delta L}\left\{\left(-\phi_{2}+\psi_{2}+4 \chi \omega-4 \alpha L \phi \omega-4 \alpha L \chi \psi\right)\left(p_{A i}-p_{B i}\right)\right. \\
& +\left(\phi_{2}-\psi_{2}-4 \chi \omega+2 \alpha L \chi_{2}+2 \alpha L \omega_{2}\right)\left(p_{A j}-p_{B j}\right) \\
& f_{4}=\frac{1}{\varepsilon}\left(-\frac{L^{2} \zeta}{6}-\frac{L \eta}{2 \lambda}+\frac{L^{2}}{3}\right)\left(p_{A i}+p_{B i}\right) \\
& +\frac{1}{\varepsilon}\left(\frac{L^{2} \zeta}{3}-\frac{L \eta}{2 \lambda}-\frac{\varepsilon}{2 \lambda^{2}}+\frac{L^{2}}{6}\right)\left(p_{A j}+p_{B j}\right) \\
& +\frac{1}{8 \alpha^{3} \delta \mathrm{L}}\left\{\left(-\omega_{2}+\chi_{2}+4 \alpha L \chi \omega-2 \chi \psi+2 \phi \omega\right)\left(p_{A i}-p_{B i}\right)\right. \\
& +\left(\omega_{2}-\chi_{2}+2 \chi \psi-2 \phi \omega+\alpha L \phi_{2}-\alpha L \psi_{2}\right)\left(p_{A j}-p_{B j}\right) \\
& f_{5}=\left(-\frac{\lambda L^{2} \eta}{12 \varepsilon}+\frac{1}{2 \lambda^{2} L}-\frac{L}{8}\right)\left(p_{A i}+p_{B i}\right) \\
& +\left(\frac{\lambda L^{2} \eta}{12 \varepsilon}-\frac{1}{2 \lambda^{2} L}-\frac{L}{8}\right)\left(p_{A j}+p_{B j}\right) \\
& -\frac{1}{8 \alpha^{2} \delta L}\left\{\left(\phi_{2}-\psi_{2}-4 \chi \omega+2 \alpha L \chi_{2}+2 \alpha L \omega_{2}\right)\left(p_{A i}-p_{B i}\right)\right. \\
& +\left(-\phi_{2}+\psi_{2}-4 \alpha L \phi \omega-4 \alpha L \chi \psi+4 \chi \omega\right)\left(p_{j j}-p_{B j}\right) \\
& f_{6}=\frac{1}{\varepsilon}\left(-\frac{L^{2} \zeta}{3}+\frac{L \eta}{2 \lambda}+\frac{\varepsilon}{2 \lambda^{2}}-\frac{L^{2}}{6}\right)\left(p_{A i}+p_{B i}\right) \\
& +\frac{1}{\varepsilon}\left(-\frac{L^{2} \zeta}{6}+\frac{L \eta}{2 \lambda}-\frac{L^{2}}{3}\right)\left(p_{A j}+p_{B j}\right) \\
& -\frac{1}{8 \alpha^{3} \delta L}\left\{\left(-\omega_{2}+\chi_{2}-2 \chi \psi+2 \phi \omega-\alpha L \phi_{2}+\alpha L \psi_{2}\right)\left(p_{A_{i}}-p_{B_{i}}\right)\right. \\
& +\left(\omega_{2}-\chi_{2}-4 \alpha L \chi \omega+2 \chi \psi-2 \phi \omega\right)\left(p_{j j}-p_{B j}\right) \\
& f_{7}=\left(\frac{\lambda L^{2} \eta}{12 \varepsilon}-\frac{1}{2 \lambda^{2} L}-\frac{L}{8}\right)\left(p_{A i}+p_{B i}\right) \\
& +\left(-\frac{\lambda L^{2} \eta}{12 \varepsilon}+\frac{1}{2 \lambda^{2} L}-\frac{L}{8}\right)\left(p_{A j}+p_{B j}\right) \\
& -\frac{1}{8 \alpha^{2} \delta L}\left\{\left(-\phi_{2}+\psi_{2}+4 \chi \omega-4 \alpha L \phi \omega-4 \alpha L \chi \psi\right)\left(p_{A i}-p_{B i}\right)\right. \\
& +\left(\phi_{2}-\psi_{2}-4 \chi \omega+2 \alpha L \chi_{2}+2 \alpha L \omega_{2}\right)\left(p_{A j}-p_{B j}\right) \\
& f_{8}=\frac{1}{\varepsilon}\left(-\frac{L^{2} \zeta}{6}-\frac{L \eta}{2 \lambda}+\frac{L^{2}}{3}\right)\left(p_{A i}+p_{B i}\right) \\
& +\frac{1}{\varepsilon}\left(\frac{L^{2} \zeta}{3}-\frac{L \eta}{2 \lambda}-\frac{\varepsilon}{2 \lambda^{2}}+\frac{L^{2}}{6}\right)\left(p_{A j}+p_{B j}\right) \\
& -\frac{1}{8 \alpha^{3} \delta L}\left\{\left(-\omega_{2}+\chi_{2}+4 \alpha L \chi \omega-2 \chi \psi+2 \phi \omega\right)\left(p_{A i}-p_{B i}\right)\right. \\
& \left.+\left(\omega_{2}-\chi_{2}+2 \chi \psi-2 \phi \omega+\alpha L \phi_{2}-\alpha L \psi_{2}\right)\left(p_{A j}-p_{B j}\right)\right\} \\
& \text { ここに, } \lambda=\sqrt{\frac{B G}{2 H}}, \alpha=\sqrt[4]{\frac{E_{f}}{2 B E I}}, \\
& \eta=\sinh (\lambda L), \zeta=\cosh (\lambda L), \phi=\cos (\alpha L), \chi=\sin (\alpha L), \\
& \psi=\cosh (\alpha L), \omega=\sinh (\alpha L), \phi_{2}=\cos (2 \alpha L), \chi_{2}=\sin (2 \alpha L) \text {, } \\
& \varepsilon=-4 \cosh (\lambda L)+2 \lambda L \sinh (\lambda L)+4, \delta=\sin ^{2}(\alpha L)-\sinh ^{2}(\alpha L), \\
& \psi_{2}=\cosh (2 \alpha L), \omega_{2}=\sinh (2 \alpha L) \text { である. }
\end{aligned}
$$

$$
\begin{aligned}
& \left(\begin{array}{c}
Q_{i} \\
M_{1} \\
Q_{j} \\
M_{j}
\end{array}\right)=-E / \beta / \delta\left(\begin{array}{cccc}
2 \beta^{2}\left(\chi_{2}+\omega_{2}\right) & \beta\left(-\phi_{2}+\psi_{2}\right) & -4 \beta^{2}(\phi \omega+\chi \psi) & 4 \beta \chi \omega \\
& -\chi_{2}+\omega_{2} & -2 \beta \chi \omega & 2(-\phi \omega+\chi \psi) \\
& & 2 \beta^{2}\left(\chi_{2}+\omega_{2}\right) & \beta\left(\phi_{2}-\psi_{2}\right) \\
& S Y M & & -x_{2}+\omega_{2}
\end{array}\right)\left(\begin{array}{c}
y_{i} \\
\theta_{i} \\
y_{1} \\
\theta_{j}
\end{array}\right)+\left(\begin{array}{c}
f_{1} \\
f_{2} \\
f_{3} \\
f_{4}
\end{array}\right) \\
& f_{1}=\frac{1}{4 \beta^{2} \delta L}\left\{\left(\phi_{2}-\psi_{2}-4 \chi \omega+2 \beta L \chi_{2}+2 \beta L \omega_{2}\right) p_{i}\right. \\
& \left.+\left(-\phi_{2}+\psi_{2}-4 \beta L \phi \omega-4 \beta L \chi \psi+4 \chi \omega\right) p_{j}\right\} \\
& f_{2}=+\frac{1}{4 \beta^{3} \delta}\left\{\left(-\omega_{2}+\chi_{2}-2 \chi \psi+2 \phi \omega-\beta L \phi_{2}+\beta L \psi_{2}\right) p_{i}\right. \\
& \left.+\left(\omega_{2}-\chi_{2}-4 \beta L \chi \omega+2 \chi \psi-2 \phi \omega\right) p_{j}\right\}
\end{aligned}
$$




$$
\begin{aligned}
f_{3}= & \frac{1}{4 \beta^{2} \delta L}\left\{\left(-\phi_{2}+\psi_{2}+4 \chi \omega-4 \beta L \phi \omega-4 \beta L \chi \psi\right) p_{t}\right. \\
& \left.+\left(\phi_{2}-\psi_{2}-4 \chi \omega+2 \beta L \chi_{2}+2 \beta L \omega_{2}\right) p_{j}\right\} \\
f_{4}= & \frac{1}{4 \beta^{3} \delta L}\left\{\left(-\omega_{2}+\chi_{2}+4 \beta L \chi \omega-2 \chi \psi+2 \phi \omega\right) p_{i}\right. \\
& \left.+\left(\omega_{2}-\chi_{2}+2 \chi \psi-2 \phi \omega+\beta L \phi_{2}-\beta L \psi_{2}\right) p_{j}\right\} \\
己 こ & \text { (18, } \quad \delta=\sin ^{2}(\beta L)-\sinh ^{2}(\beta L), \quad \beta=\sqrt[4]{\frac{E_{s}}{4 E I},} \\
\phi= & \cos (\beta L), \chi=\sin (\beta L), \psi=\cosh (\beta L), \\
\omega= & \sinh (\beta L), \quad \phi_{2}=\cos (2 \beta L), \quad \chi_{2}=\sin (2 \beta L), \\
\psi_{2}= & \cosh (2 \beta L), \quad \omega_{2}=\sinh (2 \beta L) \text { である. }
\end{aligned}
$$

\section{（2）その他の部材の部材剛性方程式}

多様な構造条件等に対応するために, 大堀らの法では考 慮されていない頂版等の梁部材に関して, 下記に示す部材 剛性方程式を適用する.

a) 設計(仮想) 地盤面上部（上部構造）における部材

・設計(仮想)地盤面上部の増し杭，頂版など 部材岡性方程式は式(16) と同様である.

・タイ材など

部材岡性方程式は式(15)を準用できる.

b) 設計(仮想) 地盤面下部（下部構造）における部材

・設計(仮想)地盤面下部の増し杭など

部材剛性方程式は式(17)を準用できる.

\section{4. 中詰土を有する壁体構造物の力学的挙動解 析の基本と解析フロー}

\section{(1) 力学的挙動解析の基本}

a) 全体䣓性方程式

部材岡性マトリックスを所定の手続きにより全体岡性 マトリックスへ重ね合わせることにより中詰土を有する 壁体構造物の全体用性方程式として式(19)を得る.

$$
\{F\}=[K]\{u\}+\{f\}
$$

ここに, $\{F\}$ は外力ベクトル, $[K]$ は全体剛性マトリック ス, $\{u\}$ は変位ベクトル, $\{f\}$ は分布荷重ベクトルである.

\section{b) 大堀らの方法に特有の処理}

大堀らの方法では，中詰土の層間におけるせん断力の不 連続性を評価するために, 層間におけるせん断力の差を集 中荷重とし評価する等特有の処理を行っている. 本解析法 でも, 明らかに大堀らの方法に特有の事項についてはこれ に準じた処理を行っている.

\section{c）壁体構成部材上端の境界条件}

壁体構成部材上端における境界条件は，頂版等の拘束が ない場合には自由端とする. 頂版を有する場合, 大堀らの 方法では上端部の境界条件を固定ローラーとみなし, 単独 部材として扱っている. このため, 頂版の変形や断面力に 関する情報を得ることができない，本文に示す解析手法 によれば, 大堀らの方法のような操作は不要であり,壁体 構成部材と頂版部材の交点を岡結合節点とすればよい．

\section{d）付加部材の処理}

增し杭等の付加部材についても㓮性マトリックス 法の解析手法に基いて処理すればよい.
（2）剛性マトリックス法による解析フロー

剛性マトリックス法による中詰土を有する壁体構 造物の力学的挙動の解析フロー概要を図-4に示す.

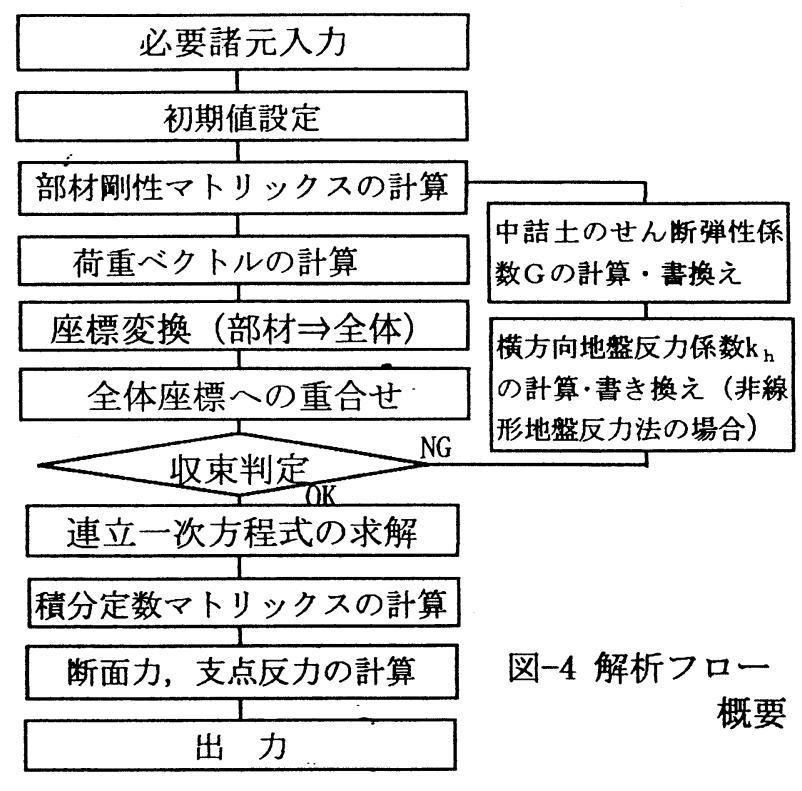

\section{5. 中詰土を有する壁体構造物の解析例}

\section{（1）解析対象構造と解析条件}

解析対象構造を図一に示す. (a) は頂版結合タイプ(基本タイ プ，(b)は従来，計算が困難であった増し杭タイプである. 解 析条件愒一6に示したとおりである. なお,ここでは解析例を 示すことを目的としているので, (a), (b) タイプとも壁体構成 部材 (鋼管矢板) は同一部材 $(\Phi 1200 \times 23 \mathrm{t}$, 継手有效間隔 $78.7 \mathrm{~mm}$, SKY490) としている. また増し杭に使用する鎙管杭は 壁体構成部材と同一の鋼管断面とし, その法線方向の配置 ピッチを 3 種類 $(1278,2557,3836 \mathrm{~mm})$ に変化させている.

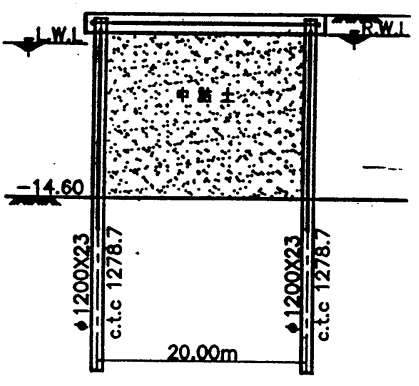

（a）頂版結合タイプ(基本タイプ)

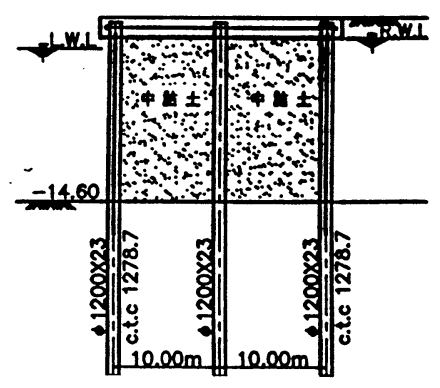

(b) 増し杭タイプ
図-5 解析対象構造

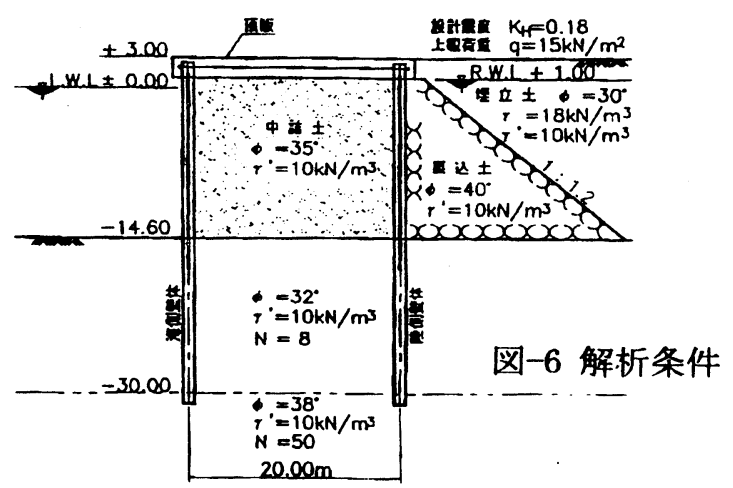


(2) 解析結果

地震時に対する解析結果を図-7に示す.

(1) 壁体及び増し杭の曲げモーメント

海側及び陸側壁体の最大曲げモーメントMmaxは 土中部で発生している. 基本タイプのそれは, 海側 壁体で約 $5080 \mathrm{kN} \cdot \mathrm{m} / \mathrm{m}$, 陸側壁体で約 $3710 \mathrm{kN} \cdot \mathrm{m} / \mathrm{m}$ であ るが, 増し杭のピッチを密にするに従いMmaxは減 少し, 最大でそれぞれ約 $25 \%$ 及び $30 \%$ 程度減少し ている.増し杭のMmaxは頂版との結合部に発生し ており,増し杭のピッチを密にするに従いMmaxは 増加し, 最大で約 $4400 \mathrm{kN} \cdot \mathrm{m} / \mathrm{m}$ 程度となっている.

(2) 頂版の断面力

頂版の最大曲げモーメントMmaxは海側壁体の直 上部で発生している.基本タイプの $\mathrm{M} \max$ は約 $5020 \mathrm{kN} \cdot \mathrm{m} / \mathrm{m}$ であるが, 増し杭ピッチが密になるに従 い減少し, 最大で約 $40 \%$ 程度减少している。

(3) 水平変位

基本タイプの天端水平変位 $\delta_{\mathrm{H}}$ は約 $24 \mathrm{~cm}$ であるが, 増し杭のピッチを密にするに従い $\delta_{\mathrm{H}}$ は減少し, 最大 で約 $30 \%$ 程度減少している.

(4) 壁体及び増し杭の軸方向力

図示していないが, 基本タイプの海側壁体には約 $1150 \mathrm{kN} / \mathrm{m}$ の押込力が発生している.この押込力は増 し杭ピッチを密にするに従い减少し,最大で約 $20 \%$ 程度減少している.また, 基本タイプの陸側壁体に は約 $300 \mathrm{kN} / \mathrm{m}$ の押込力が発生している.この押込力 も増し杭ピッチを密にするに従い减少し, 最も密な ピッチでは約 $20 \mathrm{kN} / \mathrm{m}$ の抜力となっている.なお, 增し杭には490〜 $580 \mathrm{kN} / \mathrm{m}$ の押込力が発生している.
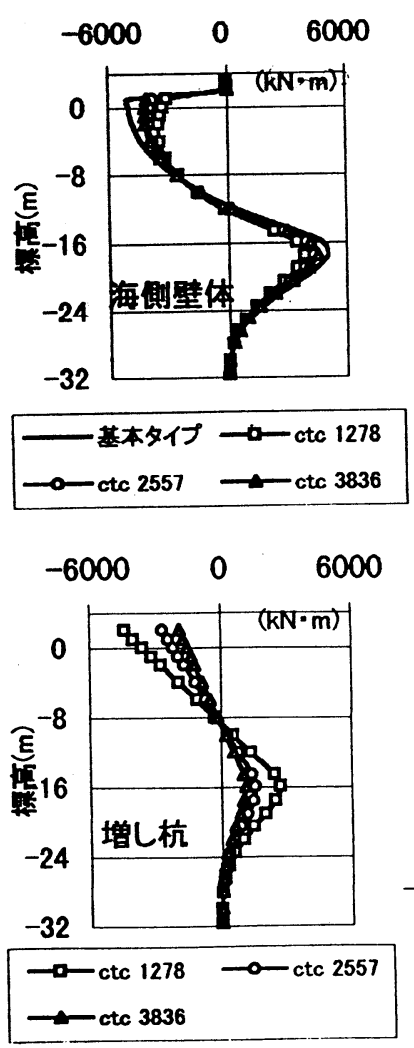
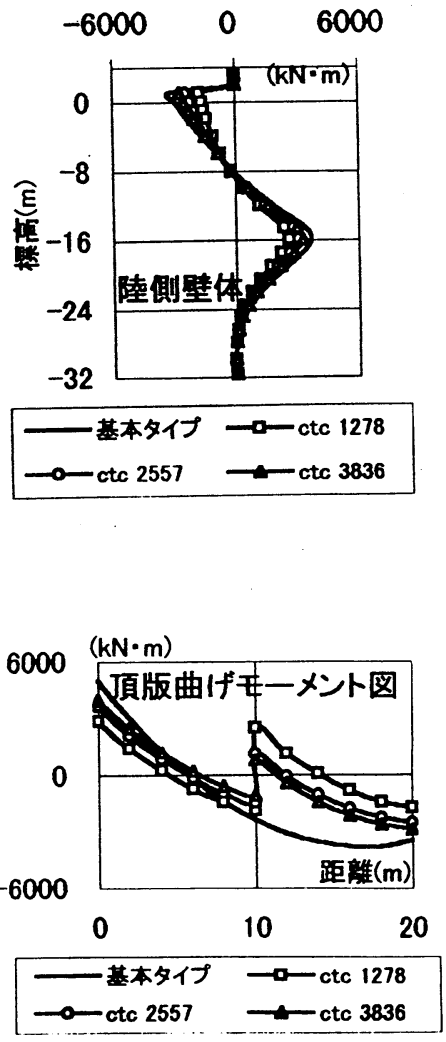

\section{6.おわりに}
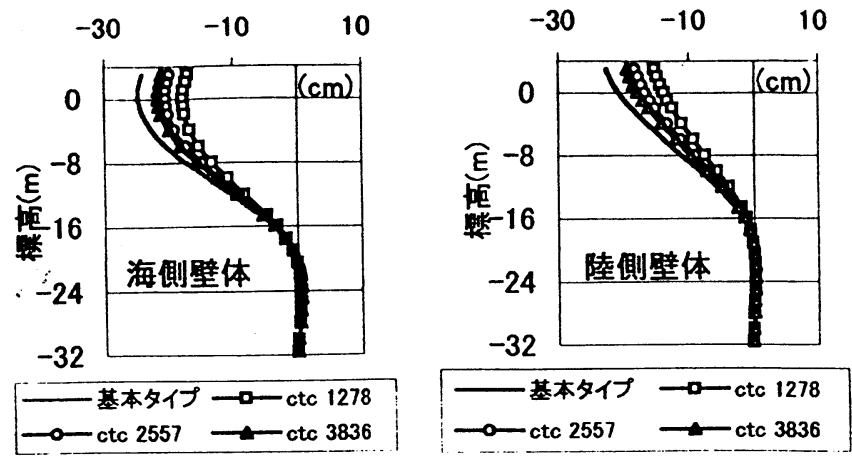

図 $-7(b)$ 変位分布

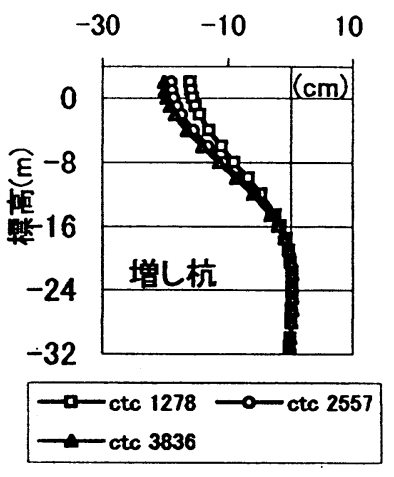

二重壁式構造物の適用範囲が拉大するに伴い,その力学 的挙動を的確に反映した設計法の開発が求められていた. また, 従来の二重壁式構造物は図-1 (a), (b)に示した頂版 結合タイプかタイ材結合タイプのどちらかという画一化 された構造形式であった.これは, 今回解析例で示した増 し杭タイプ等に対する力学的挙動の計算が困難であった ことも一因しているものと考えられる.

今回報告した解析手法によれば, (1)頂版結合タイプにお ける頂版の断面力及ひ壁体構成部材の軸方向力等 (2)増し 杭等の付加部材が存在する構造の力学的挙動 (3)中詰土の 天端が低い構造の力学的挙動 を算定することができる.

また, 二重壁式構造物をはじめとする中詰土を有する壁 体構造物に関する新たな構造形式の力学的挙動の推定が 可能となる.

なお, 本解析法では中詰土の中に杭などの付加部材を配 置したときでも, 中詰土と壁体との相互作用に関しては大 堀らの方法で示された支配方程式等に基づき挙動するも のと仮定している. 実際には，この付加部材の存在が中詰 土や壁体の挙動に少なからず影響を与える場合があるが， 本解析法ではこの点が考慮されていないことに留意する 必要がある。

\section{【参考文献】}

1）港湾の施設の技術上の基淮·同解説，(社）日本港湾協会, pp. 815 818, 1999 .

2) 沢口正俊 : 二重壁構造物の設計法についての一提案, 港湾技研資料, No. 132, pp. 3 13, 1972.

3）大堀晃一・荘司喜博·高橋邦夫·上田寬·原道彦・川井豊·塩 田啓介: 二重矢板式構造物の力学的特性に関する研究 港 湾技術研究所報告, 第29巻, 第 1 号, pp103 151. 1984.

4) H·C・マーチン著·吉識雅夫監訳 : マトリックス法によ る構造力学の解法, (株)培風館. pp. 11〜41, 1973. 